\title{
ANALYZING THE USES OF FACEBOOK ADVERTISING AS A SOCIAL MEDIA MARKETING TECHNIQUE OF A BANK: A STUDY ON A PRIVATE BANK LIMITED
}

\author{
Abdullah Al Mamun \\ Master of Business Administration \\ Department of Marketing \\ Faculty of Business Studies \\ Bangabandhu Sheikh Mujibur Rahman Science and Technology University \\ Gopalganj-8100, Bangladesh \\ E-mail: abdullahalmamun394@gmail.com \\ Apu Chandra Saha \\ Master of Business Administration \\ Department of Marketing \\ Faculty of Business Studies \\ Bangabandhu Sheikh Mujibur Rahman Science and Technology University \\ Gopalganj-8100, Bangladesh \\ E-mail: apuchandrasaha10@gmail.com \\ Asraful Islam \\ Master of Business Administration \\ Department of Marketing \\ Faculty of Business Studies \\ Bangabandhu Sheikh Mujibur Rahman Science and Technology University \\ Gopalganj-8100, Bangladesh \\ E-mail: sisir.dew7007@gmail.com
}

Received: November 30, $2021 \quad$ Accepted: December 22, $2021 \quad$ Online Published: February 5, 2022

DOI: 10.46281/ijmri.v6i1.1590

URL: https://doi.org/10.46281/ijmri.v6i1.1590

\begin{abstract}
In the era of globalization, the media is the essential fact of advertising in the competitive market. The main objective of this report is to analyze the uses of Facebook Advertising as a Social Media Marketing Techniques of a private bank. Data were collected using a survey questionnaire. The targeted respondents of this study were bank employees of a private bank, the Lohagara-Narail branch. Both male and female respondents have answered the questionnaire. Data were analyzed quantitatively using SPSS, which was a statistical method for analyzing numerical data. Both primary and secondary data were necessary for the fulfillment of the research project. Secondary data were collected from various published documents in related books, journals, social media,
\end{abstract}


and websites. For getting primary data, respective respondents were interviewed personally to collect the data required through a structured questionnaire with marketing experts and employees from some reputed and leading companies that were descriptive research question and also a faceto-face interview with the customers that was exploratory research question. A five-point Likert scale has been used for study purposes. To attain customer attention, Facebook marketing is directly associated with the benefits of the social media platform. From this study, the employee and customers can know about Facebook Advertising as a Social Media Marketing Techniques.

Keywords: Social Media, Marketing.

\section{JEL Classification Codes: M31.}

\section{INTRODUCTION}

Recently social media plays a crucial role to publish an advertisement for the company in the competitive market. Facebook is fast and most publicity platform for the advertisement of every organization either offline or online. In the case of economic growth, the banking sector plays an important role in Bangladesh (Rahaman et al., 2021; Karim, 2020; Kumar et al., 2019; Latif et al., 2019; Karim et al., 2018; Asheq et al., 2021; Islam et al., 2014; Akther et al., 2021; Asheq et al., 2021). The house we live in may have been mortgaged to a private bank, the car we drive or the taxi and the bus we ride to our office may have been bought with money borrowed from yet another bank. The businesses we see around have their links with banks; they might have borrowed money from a bank to finance their working capital or fixed assets. If nothing else, they will have at least a current or a savings account for the deposit of the day's sale proceeds. If we want to invest our money for profit or simply to hide it from the prying eyes or nimble fingers of all the wrong people in the wrong places we can step into the nearest branch of a private bank. So, it is clear that Bank and Banking business is very much important for us in all aspects and steps of our life. The last two decades have seen a revolutionary development in the banking field of Bangladesh. The expansion of the branches of private banks, privatization of major national banks, introduction of the scheme of social control, have all resulted in the growth of banking habits among the people and the realization by private banks of their social responsibilities. Basic changes are being introduced in the working patterns of private banks so that they can fit in well in our new economic and social system. On account of the growing importance of banking institutions, most universities and educational institutions give priority to the study of banking and its industry. This study provides a more important study for a bank of the uses of Facebook advertising as a social media Marmarketingchnique. At present, every financial organization works for developing our livings in various ways. They try to make a wonderful atmosphere for their work as well as in our society. There are so many strategies to work with the customers and environments. So this organization tries to get into the customer's mind on the uses of Facebook advertising than any other strategy or concept. This concept is more beneficial for making customers satisfied along with environmental benefits. Facebook advertising as a social media marketing technique is a platform that helps to increase the number of subscribers. This allows the customer to know its advantages and disadvantages very quickly. Facebook advertising as a social media marketing technique is a very helpful platform for which a private bank easily increases the number of new subscribers. Facebook advertising as a social media marketing technique This is a social media platform that allows a private bank to inform customers about their services and customers can easily access information at home. The private bank has thus benefited more loyal customers and newly 
admitted customers by using the platform (Tu et al., 2021; Ara et al., 2015; Ali et al., 2021; Ali et al., 2020; Baqir et al., 2020; Batool et al., 2021; Islam \& Bhuiyan, 2021; Islam \& Barghouthi, 2017; Islam et al., 2014; Islam \& Miajee, 2018; Islam, 2016a; Islam, 2016b; Islam, 2016c; Islam et al., 2015; Hossain et al., 2017; Islam, 2015; Islam \& Barghouthi, 2017; Islam et al., 2021). Therefore, the majority of people think that social media is a mere platform available for sharing their daily updates and pictures on social networking sites such as Facebook and Twitter (Papasolomou and Melanthiou, 2012). The project paper is more important for private bankers to know the significance of the uses of Facebook marketing. The private bank owners of Bangladesh should follow social media marketing for knowing information to the targeted customers of the market.

\section{LITERATURE REVIEW}

Facebook advertising is the crucial social media of advertising which offers consumers to like and share the opportunity of products and services(Akhter et., 2020; Karim et al., 2015; Mahmud et al., 2015). Facebook creates wide platforms for viral online services (Smock et al., 2011). This advertisement determines the potential customers of the market (Dehghani and Tumer, 2015). Facebook advertising to social media customers on social media platforms, Facebook advertising provides a way for social media marketing and advertising technologies to connect with and reach the business industry and allow them to improve their business information (Rehman et al., 2014). On the other hand, Carmichael and Cleave (2012) also stated that, advertised on Facebook and monitored two advertisements to capture the user-advert interaction and its effectiveness for small businesses. For the amount a small business would invest in such social media advertising, they found that this form of advertising could substantially improve the visibility of such businesses and easily redirect consumer traffic to the advertised business page. However, the customer's satisfaction depends on advertisement where social media like Facebook, youtube give information to the targeted customers (Karim et., 2014; Sharif et al., 2017; Latif et al., 2021; Karim et al., 2021). Therefore, FB has a variety of applications and features such as FB groups, newsfeeds reviews, events. These features enable companies to have an interactive relationship with their customers and Advertising messages offered by brands through FB advertising have an enforcing attitudinal stimulus on purchase intentions (Duffett, 2015). Furthermore, the main aim of using social media for promotion and communication is to shape the consumer's decision-making process which helps to create purchase intention among them(Tuten and Solomon, 2017).

\section{METHODOLOGY}

The study is both qualitative, quantitative in nature. The Data was collected using a survey questionnaire. Data were analyzed quantitatively using SPSS, which was a statistical method for analyzing numerical data. The targeted population of this study was the employees of a private bank. Both primary and secondary data were necessary for the fulfillment of the research project. Secondary data was collected from various published documents in related books, journals, social media, and websites. For getting primary data, respective respondents were interviewed personally to collect the data required through a structured questionnaire with marketing experts and employees from some reputed and leading companies that were descriptive research question and also a face-to-face interview with the customers that was the exploratory research question. The researcher used Likert scaling technique as sample scaling when 1=Strongly Agree, 2=Agree, 3=Neutral, 4=Disagree, 5=Strongly Disagree and open-ended question. 
Table 1. Gender status of respondents

\section{RESULTS \& DISCUSSION}

\begin{tabular}{|c|c|c|}
\hline Name & Frequency & female \\
\hline Female & 18 & 19.4 \\
\hline Male & 75 & 80.6 \\
\hline Total & 93 & 100.0 \\
\hline
\end{tabular}

The table above shows that $80.6 \%(n=75)$ of the respondents are male and the rest $19.4 \%(n=18)$ of the respondents are female.

Table 2. Facebook marketing strategy techniques very effective way

\begin{tabular}{|l|l|l|}
\hline & Frequency & Percent \\
\hline Agree & 44 & 47.3 \\
\hline Disagree & 4 & 4.3 \\
\hline Neutral & 13 & 14.0 \\
\hline Strongly Agree & 28 & 30.1 \\
\hline Strongly Disagree & 1 & 1.1 \\
\hline Total & 93 & 100.0 \\
\hline
\end{tabular}

This table above shows that $47.3 \%$ (n-44) of the respondent strongly agreed that a private bank uses Facebook marketing strategy techniques very effective way. By the information of this table, this is evidence that using a private bank uses Facebook marketing strategy techniques very effective way.

Table 3. Uses Facebook marketing strategy techniques are the effective marketing strategy for creating new customers

\begin{tabular}{|l|l|l|}
\hline & Frequency & Percent \\
\hline Agree & 50 & 53.8 \\
\hline Disagree & 2 & 2.2 \\
\hline Neutral & 2 & 2.2 \\
\hline Strongly Agree & 36 & 38.7 \\
\hline Total & 93 & 100.0 \\
\hline Agree & 50 & 53.8 \\
\hline
\end{tabular}

This table above shows that $53.8 \%$ (n-50) of the respondent strongly agreed that Uses Facebook marketing strategy techniques are the effective marketing strategy for creating new customers. By the information of this table, this is evidence that using Uses Facebook marketing strategy techniques are the effective marketing strategy for creating new customers. 
Table 4. By using Facebook marketing strategy techniques, private bank can reach their potential customer's

\begin{tabular}{|l|r|r|}
\hline & Frequency & Percent \\
\hline Agree & 46 & 49.5 \\
\hline Disagree & 3 & 3.2 \\
\hline Neutral & 9 & 9.7 \\
\hline Strongly Agree & 32 & 34.4 \\
\hline Total & 93 & 100.0 \\
\hline Agree & 46 & 49.5 \\
\hline
\end{tabular}

This table above shows that $49.5 \%$ (n-46) of the respondent strongly agreed that by uses Facebook marketing strategy techniques private bank can reach their potential customer's. By the information of this table, by uses Facebook marketing strategy techniques private bank can reach their potential customer's.

Table 5. Facebook marketing strategy techniques are profitable

\begin{tabular}{|l|r|r|}
\hline & Frequency & Percent \\
\hline Agree & 46 & 49.5 \\
\hline Disagree & 1 & 1.1 \\
\hline Natural & 1 & 1.1 \\
\hline Neutral & 11 & 11.8 \\
\hline Strongly Agree & 31 & 33.3 \\
\hline Total & 93 & 100.0 \\
\hline
\end{tabular}

This table above shows that $49.5 \%$ (n-46) of the respondent strongly agreed that Facebook marketing strategy techniques are profitable for a private bank. By the information of this table, Facebook marketing strategy techniques are profitable for a private bank

Table 6. Facebook advertising is an important area through which a private bank can easily capture the attention of the customer

\begin{tabular}{|l|r|r|}
\hline & Frequency & Percent \\
\hline Agree & 50 & 53.8 \\
\hline Neutral & 13 & 14.0 \\
\hline Strongly Agree & 27 & 29.0 \\
\hline Total & 93 & 100.0 \\
\hline Agree & 50 & 53.8 \\
\hline Neutral & 13 & 14.0 \\
\hline
\end{tabular}

This table above shows that 53.8\% (n-50) of the respondent strongly agreed that Facebook advertising is an important area through which a private bank can easily capture the attention of the customer. By the information of this table, Facebook advertising is an important area through which a private bank can easily capture the attention of the customer. 
Table 7. Private Bank can inform about the bank's offers in the easiest way through Facebook advertisement

\begin{tabular}{|l|r|r|}
\hline & Frequency & Percent \\
\hline Agree & 56 & 60.2 \\
\hline Disagree & 2 & 2.2 \\
\hline Neutral & 4 & 4.3 \\
\hline Strongly Agree & 28 & 30.1 \\
\hline Total & 93 & 100.0 \\
\hline Agree & 56 & 60.2 \\
\hline
\end{tabular}

This table above shows that $63.4 \%$ (n-56) of the respondent strongly agreed that private bank can inform about the bank's offers in the easiest way through Facebook advertisement. By the information of this table, a private bank can inform about the bank's offers in the easiest way through Facebook advertisement.

Currently, Facebook advertising is the most important strategy as a social media marketing strategy to work directly with the customer and the environment. It plays an important role in the development of our society. The paper seeks to identify and analyze the use of Facebook advertising as a new marketing strategy by a private bank in Lohagarh, Narail, and to suggest some guidelines for Facebook user authorities. Advertising as a social media marketing strategy as a new marketing strategy. The first objective of the study was to identify the use of Facebook ads as a social media marketing strategy at a private bank in Narail. Above all, private banks deliberately use Facebook ads as a social media marketing strategy because this feature helps in increasing the number of customers and informing them about the benefits. But Facebook advertising uses more profitable marketing strategies in our country. First, it can be said that the uses of Facebook advertising marketing strategy techniques are very effective way because it is used by the banking company for the convenience of the customer. This is just as important for the time being as it is for the economics of the customer.The second part said that Facebook's marketing strategy techniques are the effective marketing strategy for creating new customers. As much as the banking company can satisfy the customer through Facebook advertising social media marketing techniques, the private bank officials keep getting new customers for their bank and take stability in all aspects. Thirdly, Facebook marketing strategy techniques bank can reach their potential customers. The banking service organization and we know that private banks have more customer satisfaction than any other private bank through which the bank gains potential customers. Fourthly, Social Security platforms such as Facebook, Twitter, Linkedin, and other social media are profitable for a bank. Fifthly, security is important to place for Islami bank's Facebook advertising social media marketing techniques through which banking institutions can easily get customers. a bank easily attract the attention of the customer and customer's mind. Sixthly, a private bank can inform about the private bank's offers most easily through Facebook advertising. Facebook advertising is a platform where you can learn about new offers at home in a very simple and easy way. Now is the age of social media where everyone from 18 to $18+$ is connected with social media. So a private bank can easily inform about their services or new services through Facebook advertising. After all, if a company uses Facebook advertising as a social media marketing strategy, it can change the state of society for the better. 


\section{CONCLUSION}

Advertising plays an important role in all fields. By attracting the attention of the customer through advertisement, the customer will get to know about a private bank. A private bank flows the subject and pushes the advantages and disadvantages to the customer through marketing strategy which attracts attention. a private bank is receiving greetings very quickly.

\section{AUTHOR CONTRIBUTIONS}

Conceptualization: Abdullah-Al-Mamun, Apu Chandra Saha, Asraful Islam

Formal Analysis: Abdullah-Al-Mamun, Apu Chandra Saha, Asraful Islam

Funding Acquisition: Apu Chandra Saha, Asraful Islam

Investigation: Abdullah-Al-Mamun

Methodology: Abdullah-Al-Mamun

Project Administration: Apu Chandra Saha, Asraful Islam

Resources: Abdullah-Al-Mamun, Apu Chandra Saha, Asraful Islam

Software: Abdullah-Al-Mamun, Apu Chandra Saha, Asraful Islam

Supervision: Abdullah-Al-Mamun, Apu Chandra Saha, Asraful Islam

Validation: Abdullah-Al-Mamun, Apu Chandra Saha, Asraful Islam

Visualization: Abdullah-Al-Mamun, Apu Chandra Saha, Asraful Islam

Writing - Original Draft: Abdullah-Al-Mamun

Writing - Review \& Editing: Abdullah-Al-Mamun, Apu Chandra Saha, Asraful Islam

\section{CONFLICT OF INTEREST STATEMENT}

The authors declare that they have no competing interests.

\section{ACKNOWLEDGEMENT}

All authors contributed equally to the conception and design of the study.

\section{REFERENCES}

Ali, M. C., Islam, K. A., Chung, S. J., Zayed, N. M., \& Islam, K. M. A. (2021). The Correlation Between Job-Hopping Attitude And Turnover Behavior: A Job Satisfaction Perspective In Bangladesh. International Journal of Business and Management Future, 5(1), 14-26.

Ali, M. C., Islam, K. M. A., Chung, S. J., Zayed, N. M., \& Afrin, M. (2020). A Study of Green Human Resources Management (GHRM) and Green Creativity for Human Resources Professionals. International Journal of Business and Management Future, 4(2), 57-67.

Baqir, M., Hussain, S., Waseem, R., \& Islam, K. M. A., (2020). Impact of Reward and Recognition, Supervisor Support on Employee Engagement. American International Journal of Business and Management Studies, 2(3), 8-21.

Batool, N., Hussain, S., Baqir, M., Islam, K. M. A., \& Hanif, M. (2021). Role of HR Technology And Training For The Development Of Employees. International Journal of Business and Management Future, 5(1), 1-13.

Al Amin, M., Arefin, M. S., Sultana, N., Islam, M. R., Jahan, I., \& Akhter, A. (2020). Evaluating the customers' dining attitudes, e-satisfaction and continuance intention toward mobile 
food ordering apps (MFOAs): evidence from Bangladesh. European Journal of Management and Business Economics, 30(2), 211-229. https://doi.org/10.1108/EJMBE04-2020-0066

Akhter, A., Karim, M. K., \& Islam, A.K. (2021). The impact of emotional intelligence, employee empowerment and cultural intelligence on commercial bank employees' job satisfaction. Banks and Bank Systems, 16(4), 11-21. doi:10.21511/bbs.16 (4).2021.02

Akhter, A., Asheq, A. A., Hossain, M. U. \& Karim, M. K. (2020). Exploring customer intentions to adopt mobile banking services: evidence from a developing country. Banks and Bank Systems, 15(2), 105-116. http://dx.doi.org/10.21511/bbs.15(2).2020.10

Akhter, A., Asheq, A. A., Hossain, M. U., \& Karim, M. K. (2020b). Exploring customer intentions to adopt mobile banking services: Evidence from a developing country. Banks and Bank Systems, 15(2), 105-116.

Asheq, A.A., Tanchi, K.R., Kamruzzaman, M., \& Karim, M.M. (2021). The impact of e-marketing orientation, technological orientation, and learning capacity on online SME performance. Innovative Marketing, 17(3), 168-179. doi:10.21511/im.17(3).2021.14

Carmichael, D., \& Cleave, D. (2012). How effective is social media advertising? A study of facebook social advertisements. Paper presented at the 2012 International Conference for Internet Technology and Secured Transactions, ICITST 2012, 226-229.

Dehghani, M., \& Tumer, M. (2015). A research on the effectiveness of Facebook advertising on enhancing the purchase intention of consumers. Computers in human behavior, 49, 597600.

Duffett, G. R. (2015). Facebook advertising's influence on intention-to-purchase and purchase amongst Millennials. Internet Research, 25(4), 498-526.

Islam, K. M. A., \& Bhuiyan, A. B. (2021). Determinants of the effectiveness of internal Shariah audit: Evidence from Islamic banks in Bangladesh. The Journal of Asian Finance, Economics, and Business, 8(2), 223-230.

Islam, K. M. A., \& Barghouthi, O. A. (2017). Risk Management of Islamic Banking: An Islamic Perspective. International Journal of Islamic Banking and Finance Research, 1(1), 25-28.

Islam, K. M. A., \& Miajee, M. R. K. (2018). Small and Medium Enterprises (SMEs) Financing in Bangladesh: A Review of Literature. International Journal of Small and Medium Enterprises, 1(1), 11-15.

Islam, K. M. A. (2016a). Financial Performance Comparison of Top Rated Banking Financial Institutions (BFIs) of Bangladesh. Indian Journal of Science, 23(85), 669-697.

Islam, K. M. A. (2016b). Factors influencing consumers purchase decision: a case study of Pantene shampoo. Indian Journal of Science, 23(88), 910-923. 
Islam, K. M. A. (2016c). Corporate Governance: Conjecture and Modernism. Indian Journal of Science, 23(86), 798-817.

Islam, K. M. A., Alam, I., \& Al-Amin, D. M. (2015). Foreign exchange operation of private commercial banks in Bangladesh: A case study on AB Bank Limited. International Journal of Innovative Research and Creative Technology, 1(3). 296-304.

Hossain, S. A., Islam, M. N., Mahmud, M. S., \& Islam, K. M. A. (2017). Evaluation of Financial Performance of Commercial Banks in Bangladesh: Comparative Study Based on CAMEL Approach. The Millennium University Journal, 2(1), 54-77.

Hossain, M. U. (2021). Relationship between Individual Characteristics and Social Entrepreneurial Intention: Evidence from Bangladesh. Business and Economics Research Journal, 12(2), 385-397.

Hossain, M. U., Arefin, M. S., \& Yukongdi, V. (2021). Personality Traits, Social Self-Efficacy, Social Support, and Social Entrepreneurial Intention: The Moderating Role of Gender. Journal of Social Entrepreneurship, 1-21.

Islam, K. M. A. (2015). Throughput accounting: a case study. International Journal of Finance and Banking Research, 1(2), 19-23.

Islam, K. M. A., Alam, I., \& Hossain, S. A. (2014). Examination of profitability between Islamic banks and conventional banks in Bangladesh: A comparative study. Research in Business and Management, 1(1), 78-89.

Islam, K. M. A., \& Barghouthi, O. A. (2017). Risk Management of Islamic Banking: An Islamic Perspective. International Journal of Islamic Banking and Finance Research, 1(1), 25-28.

Islam, K. M. A., Sadekin, M. S., Rahman, M., Chowdhury, M., \& Haque, A. (2021). The impact of Shariah supervisory board and Shariah audit committee on CSR adoption at Islamic banks. Journal of Asian Finance, Economics and Business (JAFEB), 8(3), 479-485.

Jahan, N., Ali, M. J., \& Al Asheq, A. (2020). Examining the key determinants of customer satisfaction Internet banking services in Bangladesh. Academy of Strategic Management Journal, 19(1), 1-6.

Karim, M., Islam, J. and Mahmud.L. (2014). Job Satisfaction of Employees in Banking Sector. A Case Study on Janata Bank Limited. European Journal of Business and Management, 6(17), 70-78.

Karim, M. M. (2020). Servqual Model for Measuring Customer Satisfaction: An Analysis Of Quantitative Data. Noble International Journal of Business and Management Research, 4(12), pp.117-125 
Kumar, B., Asheq, A. A., Rahaman, M., \& Karim, M. K. (2019). Determinants of Social Media Marketing Adoption Among SMEs: A Conceptual Framework. Academy of Marketing Studies Journal, 23(1), 1-9.

Latif, W.B., \& Karim, M.M. (2019). The art of developing entrepreneurial leadership. International Journal of Research in Management, 1(1), 18-21.

Papasolomou, I., \& Melanthiou, Y. (2012). Social media: Marketing public relations' new best friend. Journal of Promotion Management, 18(3), 319-328.

Rahaman, M. A., Luna, K. F., Ping, Z. L., Islam, M. S., \& Karim, M. M. (2021). Do Risk-Taking, Innovativeness, and Proactivity Affect Business Performance of SMEs? A Case Study in Bangladesh. The Journal of Asian Finance, Economics, and Business, 8(5), 689-695. doi:10.13106/jafeb.2021.vol8.no5.068

Rehman, F. U., Ilyas, M., Nawaz, T., \& Hyder, S. (2014). How Facebook advertising affects the buying behavior of young consumers: The moderating role of gender. Academic Research International, 5(4), 395-404.

Smock, A. D., Ellison, N. B., Lampe, C., \& Wohn, D. Y. (2011). Facebook as a toolkit: A uses and gratification approach to unbundling feature use. Computers in human behavior, 27(6), 2322-2329.

Karim, M., Haque, M, Dona, P.D, Moniruzzaman, M. (2015) .Performance Appraisal System of Employees of Private Banking Sector in Bangladesh. A Case Study on National Bank Limited. International Journal of Advanced Multidisciplinary Research, 2 (3), 1-5.

Mahmud, L., Azim, M., Ahmed, H., Karim, M. (2015). Dynamics of Remittance in Bangladesh. A Case Study on United Commercial Bank (UCB).Global Journal of Management and Business Research(C), 15(1).9-16.

Sharif, A., \& Karim, M. (2017). Influence of Job Analysis Program on Employees. A Study on Selected Companies of Bangladesh. International Journal of Scientific and Engineering Research, 8(5), 1221-1225

Latif, W. B., Pervin, K., \& Karim, M. (2021). The Impact Of The Fourth Industrial Age (I4. 0) On Higher Education (He4. 0): In The Perspective Of Bangladesh. International Journal of Education and Social Science Research, Vol. 4, No. 05; DOI: http://dx.doi.org/10.37500/IJESSR.2021.4501

Karim, M. M., Bhuiyan, M. Y. A., Nath, S. K. D., \& Latif, W. B. (2021). Conceptual Framework of Recruitment and Selection Process. International Journal of Business and Social Research, 11(02), 18-25. https://doi.org/10.18533/ijbsr.v11i02.1415

Tu, B., Bhowmik, R., Hasan, M., Asheq, A. A., Rahaman, M., \& Chen, X. (2021). Graduate Students' Behavioral Intention of toward Social Entrepreneurship: Role of Social Vision, 
Innovativeness, Social Proactiveness, and Risk Taking. Sustainability, 13(11), 6386.

\section{Copyrights}

Copyright for this article is retained by the author(s), with first publication rights granted to the journal. This is an open-access article distributed under the terms and conditions of the Creative Commons Attribution license (https://creativecommons.org/licenses/by/4.0). 